\title{
INVESTIGAÇÃO DAS PRÁTICAS PEDAGÓGICAS INOVADORAS NO ENSINO UNIVERSITÁRIO: UM ESTUDO DE CASO COM PROFESSORES DE EXATAS
}

\author{
Juliana de Jesus Araújo푸 Segundo Autor ${ }^{2}$ \\ 1. Bolsista CNPq/FAPESB, Graduando em Licenciatura em Matemática, Universidade Estadual de Feira de \\ Santana, e-mail: juliana.araujo789@gmail.com
}

2. Iron Pedreira Alves, Departamento de Educação, Universidade Estadual de Feira de Santana, e-mail: iron_alves@yahoo.com.br

PALAVRAS-CHAVE: Docência universitária; Inovação; Insucesso na ciências exatas.

\section{INTRODUÇÃO}

O Ensino Superior em nossa sociedade tem tido ultimamente um olhar de grande preocupação nos cursos de Ciências exatas. Tal cenário se dá para as reprovações e evasões, e um dos fatores se apresenta pelo insucesso nas disciplinas de Cálculo I e II. Preocupados com essa realidade presente na nossa universidade (UEFS) nos cursos de licenciatura em Química, Física e Matemática que nossa pesquisa surgiu com o objetivo de buscar analisar os motivos que levam os estudantes a se evadirem, a reprovarem e até mesmo as concepções dos professores sobre os determinantes da evasão e reprovação, bem como as estratégias de intervenção desenhadas para intervir nesses fenômenos.

O grande número de reprovações despertou o interesse pelo tema, visto que seja duas disciplinas de grandes dificuldades apresentas pelos estudantes, impedindo de ter êxito e somando para a evasão ou reprovação desses cursos citados acima.

Sabe-se que o Núcleo de Estudos e Pesquisas sobre Pedagogia Universitária (NEPPU) tem afinidade de objetivos em comum com a temática trabalhada, logo o mesmo propõe a pesquisa "Inovação da Pratica Pedagógica de professores do ensino universitário pela pesquisa-ação colaborativa”, com o propósito de provocar os professores da UEFS para o exercício de práticas inovadoras e com a qualidade esperada fazer face a esse contexto de mudança social. O grupo proporcionou um espaço de avaliação e discussão chegando a importância de dá prosseguimento a ideia de levantar hipóteses e chegar as conclusões aos motivos pelos quais existe uma linha de insucesso das ciências exatas.

\section{METODOLOGIA}

Diante dos objetivos traçados neste projeto, realizamos uma pesquisa de abordagem epistemológica de cunho qualitativo. Através dos estudos e reflexões do projeto de maior abrangência, o qual é coordenado pelo Núcleo de Estudos em Pedagogia Universitária (NEPPU), existente na Universidade Estadual de Feira de Santana (UEFS), intitulado: "Inovação da prática pedagógica de professores do ensino universitário pela pesquisa-ação colaborativa”, que busca investigar várias temáticas relacionadas à docência do ensino superior que deu suporte para prosseguir pesquisando.

Com o intuito de buscar compreender os fatores que levam ao alto índice de reprovação e evasão nas disciplinas de Cálculo I e II, foi aplicado dois tipos de questionários, um para estudantes e outro para professores das referidas disciplinas dos cursos de Licenciatura (Matemática, Química e Física). A análise dos dados foi feita objetivando capturar os discursos através da oralidade tendo como foco três categorias: aprendizagem, currículo e avaliação. 


\section{RESULTADOS E/OU DISCUSSÃO}

Para a apresentação dos resultados obtidos, mediante a coletas de dados dessa pesquisa, organizamos em três categorias, sendo elas: aprendizagem, currículo e avaliação. Nesse sentido, se faz necessário discutirmos o modo como docentes e discentes enxergam a trajetória da formação da área das ciências exatas, principalmente do cálculo diferencial (cálculo I) e integral (cálculo II) que é visto nesse campo como precursor de reprovações e evasões. Assim como o processo de ensino e aprendizagem, bem como as estratégias de ensino utilizadas pelos mesmos neste processo de partilha.

No que diz respeito a aprendizagem, Pereira (2007) deixa claro que na pratica docente o profissional precisa ter planejamento para alcançar resultados. Levando para a realidade do campo da universidade, especificamente das licenciaturas da área das exatas é fácil perceber pelos relatos dos professores e alunos que o indivíduo que não possui estratégia e bons planejamento acabam indo pela curva do insucesso.

Desse modo, ao analisar as respostas apresentadas pelos estudantes, a maioria declarou que preferem estudar em grupo ou assistir vídeos aulas depois das aulas dos professores. Pois não conseguiam entender as explicações destes. Os mesmos relataram que quando cursaram as disciplinas de cálculo I e II não tinham monitor, assim como alguns professores que as lecionavam davam atenção a minoria que compreendia e conseguia acompanhar o conteúdo durante a aula. Porém, existem contradições nas falas, pois os professores dizem que só frequentam as monitorias os "melhores" alunos, ou alunos desesperados apenas no final do semestre. Já um professor (PROFESSOR B) de matemática disse que os estudantes têm a cultura de tentar aprender o conteúdo apenas em casa, no momento da aula eles são apáticos e dispersos.

Com relação ao currículo Severino (2004, p.17), afirma que tendo em vista ser o professor, o “profissional da formação humana” é visível que a formação de professores nas universidades existe um resultado um pouco plausível. Situamos as deficiências dessa formação como uma das questões cruciais para os problemas que afetam a educação brasileira.

Contudo, foi questionado aos estudantes o que eles pensam sobre o currículo? Um estudante de Matemática (ESTUDANTE B) respondeu que:

“O currículo do curso é considerado como um dos melhores currículos
de licenciatura em Matemática, mas vejo que deveria melhorar em
alguns sentidos. Porque para mim que vou concluir o curso agora um
dos maiores desafios é quando estou na sala de aula, como vou passar
o conteúdo para o aluno, porque no curso a gente tem algumas
disciplinas de Matemática na área de Matemática pura, e os dos
problemas é que a forma que o professor de cálculo por exemplo passa
o conteúdo é exatamente da forma que a gente não deveria ensinar
para os alunos, ele fala alguns termos por exemplo corta, cancela só
que a gente quando vai para a sala de aula como é que a gente vai falar
da forma diferente que a gente aprendeu? Então o currículo do curso
não vejo como o currículo ruim, mas vejo como um currículo que
deve ser melhorado. E o problema talvez não seja só o currículo, mas
sim a forma do ensino principalmente nas disciplinas da matemática
pura tem um envolvimento quando dá para relacionar com o ensino
básico que a gente não vê isso na ementa do curso de licenciatura do
curso de Matemática”

Sobre a categoria avaliação pude perceber que alguns estudantes não concordam com a metodologia dos professores, pois muitos são tradicionais. Os professores entrevistados 
afirmam que um dos grandes desafios é encontrar alunos que domine a Matemática básica. Nas provas eles encontram erros absurdos, porque existem alunos que não dominam a Matemática do Ensino Fundamental II e Médio, e com esse fator, contribui para a reprovação.

Um professor de Matemática (PROFESSOR E), respondeu na segunda pergunta mencionada, que contradiz a fala do estudante sobre esclarecimentos das suas dúvidas. Pois o professor diz que:

“A maioria dos estudantes por ter um conhecimento fragmentado, ou superficial de assuntos passados, sente-se dificuldades em elaborar a pergunta, para o professor entender qual não sabe nem tirar as dúvidas e isso de qualquer forma acaba atrapalhando."

Um estudante (ESTUDANTE D) de Matemática nos diz:

\begin{abstract}
"Meu professor de cálculo I eu achei mais tradicional, era aquela aula que envolvia mais aplicação, não envolvia muito a realidade, já meu professor de cálculo II em alguns momentos ele tentava fazer com a gente visualizasse, não sei porque a disciplina envolvia gráficos de 3 dimensões isso é para visualizar precisava ver algumas figuras geométricas aí ele levou em alguns momentos. ”
\end{abstract}

\title{
CONSIDERAÇÕES FINAIS
}

É perceptível que temos elementos essências pelas falas de professores, estudantes e autores que o insucesso apresentado pelos alunos do curso de cálculo I e II é que as hipóteses levantadas no plano de trabalho realmente contribuem para a corrente de insucesso dos mesmos, essas como base, foi a que teve um percentual grande de evasões pelo lado dos pesquisados, logo, os discentes se reconhecem que entraram na universidade com a base muito baixa devido seu ensino básico.

O fenômeno da repetência e do abandono de curso no ensino superior não possui causa única, na verdade encontram-se múltiplas causas ligadas ás especialidades dos cursos, base dos estudantes, perfil dos alunos, falta de adaptação com a metodologia dos professores, dentre outros.

Diante desse cenário preocupante, é importante que a universidade possa refletir e ajudar essas áreas. Sabendo que os mesmos sugeriram um curso preparatório antes de começar o semestre com conteúdo do ensino básico para oferecerem condições suficientes de preparo para a ementa do cálculo I e o II. E que professores e estudantes 
possam levar a formação continuada com compromisso e qualidade, para assim, tornar sujeitos capazes de se inserir em qualquer área do nível superior com total domínio.

\section{REFERÊNCIAS}

PEREIRA, J. E. C. . Formação de professores: pesquisa representação e poder. Belo Horizonte: Autentica, 2007.

SEVERINO, A.J. Educação, ideologia e contra-ideologia. São Paulo, EPU, 2004 